\title{
International Study on Artemia*. XIV. Growth and Survival of Artemia Larvae of Different Geographical Origin in a Standard Culture Test
}

\author{
P. Vanhaecke and P. Sorgeloos** \\ Artemia Reference Center, State University of Ghent, J. Plateaustraat 22, B-9000 Ghent, Belgium
}

ABSTRACT: For characterization of strains of the brine shrimp Artemia of different geographical origin, a standard culture test has been developed in order to compare statistically growth and survival of larvae of different strains. 25 geographical strains have been studied so far - including, for 3 strains, analyses of cysts harvested at different times. Important differences in rates of growth and survival were observed between strains but not among batches of the same strain. Best performances were noted for strains from Bahia Salinas (Puerto Rico), Buenos Aires (Argentina), Chaplin Lake (Canada), Great Salt Lake (Utah, USA), Galera Zamba and Manaure (Colombia).

\section{INTRODUCTION}

The use of Artemia $\cdots$ as live food for larval fishes and crustaceans has, thus far, been mostly restricted to nauplii (for details consult 'Marine Ecology', Volume III: Kinne, 1977). Although it was demonstrated that, as predators grow, better survival and growth are obtained with brine shrimp larvae (Walne, 1967; Sick and Beaty, 1974; Purdom and Preston, 1977), nauplii are still preferred because of the simplicity of hatching procedures, as opposed to more labour, equipment and food costs required for raising larvae (Brouillet, 1977 in Girin, 1979). However, due to recent developments in Artemia cultivation on cheap diets (Sorgeloos et al., 1980; Dobbeleir et al., 1980) in easy-to-operate raceway systems (Bossuyt and Sorgeloos, 1980), the use of Artemia larvae and preadults in aquaculture hatcheries is gaining interest (Sorgeloos, 1980), not only because of the improved output of fish and crustacean hatcheries, but also because of substantial savings in the quantity of Artemia cysts needed for hatchery operations (Fujimura, 1978).

\footnotetext{
- International Interdisciplinary Study on Artemia strains, coordinated by the Artemia Reference Center, State University of Ghent, Belgium

- 'Bevoegdverklaard Navorser' at the Belgian National Science Foundation (N.F.W.O.)
}

Within the framework of the 'International Study on Artemia', whose goal is to improve the use of brine shrimp in aquaculture through characterization and selection studies of various geographical strains of Artemia (Sorgeloos, 1980), a comparative study of growth rates and conversion efficiencies is presently in progress. Although there is evidence that growth rates can vary significantly from one strain of brine shrimp to another (Gilchrist, 1960; Sorgeloos, 1975; Tobias et al, 1980) more information is needed, preferably obtained under standardized experimental conditions.

This paper reports on the rates of growth and survival of 25 different Artemia strains (3 of which were analyzed after differential harvesting in a standard culture test

.. The binomen Artemia salina L. is taxonomically no longer valid (see reviews in Bowen and Sterling, 1978; Bowen et al., 1980). In view of the important genetical differences between parthenogenetical strains of brine shrimp. (AbreuGrobois and Beardmore, 1980) species definition in the genus Artemia has become unclear. One of the main conclusions of the 'International Symposium on the Brine Shrimp, Artemia salina L.' (Corpus Christi, Texas-USA, Aug. 20-23, 1979) was that, unless the exact sibling species can be identified (20 bisexual strains have been classified so far into 5 sibling species by Bowen et al., 1978) and until speciation in brine shrimp is better understood, only the genus designation Artemia should be used (Persoone et al., 1980) 


\section{MATERIALS AND METHODS}

For each Artemia strain approximately $100 \mathrm{mg}$ of cysts were incubated under optimum hatching conditions (Sorgeloos, 1980). The culture experiments were carried out in test tubes filled with $25 \mathrm{ml}$ of $0.2-\mu \mathrm{m}$ filtered natural seawater and kept in darkmess at $25^{\circ} \mathrm{C}$ $\pm 0.5 \mathrm{C}^{\circ}$. Each tube was inoculated with 10 instar-I nauplii.

The Artemia larvae were fed once daily with a defined number of algal cells (Dunaliella viridis): Day $1,12 \times 10^{5}$ cells; Days 2, 3 and 4,24 $\times 10^{5}$ cells; Days 5 and $6,36 \times 10^{5}$ cells; Day $7,48 \times 10^{5}$ cells. This optimal feeding schedule has been determined by Vanhaecke and Cooreman (1979) in preliminary culturing tests with nauplii hatched from San Francisco Bay (California-USA) cysts (San Fancisco Bay Brand Company, Batch 288-2596).

The algae were cultured according to De Pauw et al. (1978), harvested in their exponential growth phase by centrifugation, then resuspended in filtered seawater and diluted to a final concentration of $12 \times 10^{6}$ cells $\mathrm{ml}^{-1}$. The suspension was then stored in darkness at $4{ }^{\circ} \mathrm{C}$ during the whole experimental period. Algal suspension was distributed with an automatic micropipet $\left(100,200,300\right.$ or $400 \mu$ tube $\left.\mathrm{u}^{-1} \mathrm{~d}^{-1}\right)$ according to feeding schedule. After each feeding the test tubes were shaken to assure good food distribution.

The number of surviving brine shrimp were counted on Day 8 , fixed with lugol's solution (100 $\mu$ l per tube). These were then transferred to microscopic slides where their length (from the anterior tip of the head along the intestine to the base of the furca) was determined by camera-obscura drawing at a magnification of $50 x$.

The minimum number of replicate test tubes necessary for statistical analysis for each geographical strain was determined according to Cohran and Cox (in Sokal and Rohlf, 1969) using data from preliminary experiments (Vanhaecke and Cooreman, 1979). Four replicate tubes assured $95 \%$ probability for detecting a $15 \%$ difference from the mean at the 0.05 level. Since higher mortalities can be expected with some experimental strains (the San Francisco Bay strain gives an average of over $90 \%$ survival) 5 replicate test tubes per strain were used. Test tubes with a survival below $70 \%$ were not taken into consideration for growth evaluation.

The culture tests are designed to enable statistical interpretation by means of a one way analysis of variance, Model I (Sokal and Rohlf, 1969). The survival data are normalized through an arc $\sin \sqrt{\text { percent }}$ transformation. The standard culture test was repeated for the strains from Shark Bay, Macau (harvested in March
1978), and from Adelaide and Great Salt Lake (harvested in 1977).

A comparison between all strains tested was possible by using the San Francisco Bay strain, Batch 288-2596 as inner standard; the growth for each strain (up to 5 strains were tested per experiment) was expressed as percentage of the growth recorded for the reference strain.

\section{RESULTS}

For the reference strain, average larval length after 7 days is $3.16 \pm 0.17 \mu \mathrm{m}$; the mean percent survival was $94.2 \pm 2.8 \%$. Growth and survival data for the 25 geographical strains tested are summarized in Table 1.

Significant differences in growth rates occur between the geographical strains studied. Compared to the reference strain, brine shrimp form Lamaca Salt Lake, Santa Pola, Salin du Giraud and an unknown locality in China grow significantly slower. In contrast, higher growth rates prevail for Artemia from Adelaide, Manaure, Bahia Salinas, Great Salt Lake, Buenos Aires, Galera Zamba and Chaplin Lake. For 14 other strains no significant differences from the reference strain could be observed. The variations between different harvests from the same strain and between the 4 repeated experimental runs are small and not significant. Furthermore, the differences in growth rates between the San Francisco Bay strain and the strains originating from either the San Francisco Bay transplantations in Macau and Barotac Nuevo (Sorgeloos et al., 1979) or the $P_{1}$ generation of San Francisco Bay cysts produced under laboratory conditions (Versichele and Sorgeloos, 1980) are statistically not significant.

With regard to percent survival, mortality rates significantly higher than in the reference strain prevail for Artemia from Bonaire, Salin du Giraud, Great Salt Lake 1966, Larnaca Salt Lake, Lavalduc, Buenos Aires, San Felix and Santa Pola. Variations between different harvests are small with the exception of the Great Salt Lake samples 1966 and 1977 . However, during the last decade this biotope has been subjected to considerable ecological changes (Stephens and Gillespie, 1972).

\section{DISCUSSION}

The standard culturing test, outlined above and tested on 25 strains, appears to be applicable for comparing Artemia strains on the basis of larval growth and mortality. Since it has been reported earlier that the optimal temperature-salinity combination can vary from one Artemia strain to another (Sorgeloos et al., 1976) it is possible that some differences in growth and 
Table 1. Artemia. Percent growth and survival of different geographical strains of brine shrimp under standard culture conditions

\begin{tabular}{|c|c|c|c|c|c|}
\hline \multirow[b]{2}{*}{ Lamaca Salt Lake (Cyprus) } & \multicolumn{2}{|c|}{$\begin{array}{c}\text { Survival at Day } 7 \\
(\%)\end{array}$} & \multicolumn{3}{|c|}{$\begin{array}{l}\text { Growth expressed as \% } \\
\text { recorded for Artemia } \\
\text { reference strain, } \\
\text { San Francisco Bay, } \\
\text { Batch } 288-2596\end{array}$} \\
\hline & $70^{\circ}$ & & 88 & & \\
\hline Santa Pola (Spain) & $76^{\circ}$ & & 88 & & \\
\hline Salin du Giraud (France) & $66^{\circ}$ & & 90 & & \\
\hline China (unknown locality) & 84 & & 91 & & \\
\hline Shark Bay (Australia) & 90 & $84^{\mathrm{a}}$ & 95 & $96^{\mathrm{a}}$ & \\
\hline San Francisco Bay (California/USA; cysts produced in the laboratory) & 92 & & 96 & & \\
\hline San Francisco Bay (California/USA; Batch No 236-2016) & 98 & & 96 & & \\
\hline Macau (Brazil; harvested in March 1978) & 84 & $96^{\mathrm{a}}$ & 96 & $98^{\mathrm{a}}$ & \\
\hline Barotac Nuevo (Philippines) & 86 & & 97 & & \\
\hline Tientsin (China) & 96 & & 98 & & \\
\hline San Francisco Bay (California/USA; Batch No 933-235) & 94 & & 99 & & \\
\hline Aigues Mortes (France) & 90 & & 99 & & \\
\hline Izmir (Turkey) & 96 & & 101 & & \\
\hline Margherita di Savoia (Italy) & 96 & & 102 & & \\
\hline San Felix (Spain) & $74^{\circ}$ & & 102 & & \\
\hline Macau (Brazil; harvested in May 1978) & 94 & & 103 & & \\
\hline Bonaire (Netherlands Antilles) & $66^{\circ}$ & & 104 & & \\
\hline San Pablo Bay (California/USA; Batch No 1628) & 90 & & 105 & & \\
\hline Port Araya (Venezuela) & 90 & & 107 & & \\
\hline Eilat (Israel) & $92^{\bullet}$ & & 107 & & \\
\hline Lavalduc (France) & $70^{\circ}$ & & 109 & & \\
\hline Adelaide (Australia) & 88 & $88^{2}$ & $113^{*}$ & $113^{\mathrm{a}}$ & \\
\hline Manaure (Colombia) & 90 & & 115 & & \\
\hline Bahia Salinas (Puerto Rico) & 88 & & 122 & & \\
\hline Great Salt Lake (Utah/USA; harvested in 1977) & 94 & $94^{a}$ & 119 & $125^{\mathrm{a}}$ & \\
\hline Buenos Aires (Argentina) & $72^{\circ}$ & & 126 & & \\
\hline Galera Zamba (Colombia) & 98 & & 126 & & \\
\hline Great Salt Lake (Utah/USA; harvested in 1966) & $66^{\circ}$ & & 127 & & \\
\hline Chaplin Lake (Canada) & 88 & & 130 & & \\
\hline \multicolumn{6}{|l|}{$\begin{array}{l}\text { a result of replicate test in time } \\
\text { - significantly different from the reference strain at the } 0.05 \text { level } \\
\text { - significantly different from the reference strain at the } 0.01 \text { level }\end{array}$} \\
\hline
\end{tabular}

survival between the strains studied have been masked by our present culture technology $\left(25^{\circ} \mathrm{C}\right.$; natural seawater of ca $35 \mathrm{ppt}$ ). In any case, the order of growth performance reported by Sorgeloos (1975) for three strains (San Francisco Bay, Great Salt Lake and China) is identical to the sequence obtained here for the same strains.

In this study, all Artemia strains that grew significantly faster than the reference strain were bisexual. However, Gilchrist (1960) reported that a parthenogentic strain from La Palme (France) grew faster than a bisexual Artemia from San Diego (California, USA). It appears from our results that this observation cannot be ascribed to a difference in growth rate related to the mode of reproduction. Our study provides further evidence that growth rates of Artemia larvae are straindependent. There are indications that this phenomenon might be genetically controlled: the strains produced from San Francisco Bay inoculations in Brazil and the Philippines, or from a San Francisco Bay population maintained under laboratory conditions exhibited growth performances similar to the parental strains.

While brine shrimp strains between which the genetic distance is known to be large (e. g. Buenos Aires and Chaplin Lake; Abreu-Grobois and Beardmore, 1980) can have similar growth rates, different rates may be observed in strains of the same sibling species, e. g. from Chaplin Lake and San Francisco Bay, which are both Artemia franciscana (Bowen et al., 1978). It is furthermore interesting to note that no correlation exists between growth rates and biometrical characteristics of nauplii from corresponding strains (Vanhaecke and Sorgeloos, 1980).

With regard to the practical use of Artemia in aquaculture, the results reported here provide a guideline for the selection of specific geographical strains. While data on growth rates are useful, addi- 
tional criteria should be taken into consideration. Accordingly, our comparative analyses have now been extended to include biomass production, food conversion efficiency and temperature-salinity preferences.

Acknowledgements. We are greatly indebted to the many people who provided us with cyst samples from different geographical brine shrimp strains. This study was supported by the Belgian National Science Foundation (N. F. W O.) through Grant F. K. F. O. -2.0010 .78 .

\section{LITERATURE CITED}

Abreu-Grobois, F. A., Beardmore, J. A. (1980). International study on Artemia. II. Genetic characterization of Artemia populations - an electrophoretic approach. In: Persoone, G., Sorgeloos, P., Roels, O. A., Jaspers, E. (eds) The brine shrimp Artemia, Vol. 1, Morphology, genetics, radiobiology, toxicology. Universa Press, Wetteren, Belgium, in press

Bossuyt, E., Sorgeloos, P. (1980). Technological aspects of the batch culturing of Artemia in high densities. In: Persoone, G., Sorgeloos, P., Roels, O. A., Jaspers, E. (eds) The brine shrimp Artemia, Vol. 3, Ecology, culturing, use in aquaculture. Universa Press, Wetteren, Belgium, in press

Bowen, S. T. Davis, M. L., Fenster, S. R., Lindwall, G. A. (1980). Sibling species of Artemia. In: Persoone, G., Sorgeloos, P., Roels, O. A., Jaspers, E. (eds) The brine shrimp Artemia, Vol. 1, Morphology, genetics, radiobiology, toxicology. Universa Press, Wetteren, Belgium, in press

Bowen, S. T., Durkin, J. P., Sterling, G., Clark, L. S. (1978). Artemia hemogloblins: genetic variation in parthenogenetic and zygogenetic populations. Biol. Bull. mar biol. Lab., Woods Hole 155: 273-287

Bowen, S. T., Sterling, G. (1978). Esterases and malate dehydrogenase isozyme polymorphisms in 15 Artemia populations. Comp. Biochem. Physiol. 61B: 593-595

Brouillet, S. (1977). Approche technique et économique comparée d'écloseries-nurseries de bar et de la sole. Mémoire de DEA Halieutique, $79 \mathrm{pp}$

De Pauw, N., Bruggeman, E., Persoone, G. (1978). Research on the tertiary treatment of swine-waste by mass culturing of algae. Mitt. internat. Verein. Limnol. 21.490-506

Dobbeleir, J., Adam, N., Bossuyt, E., Bruggeman, E., Sorgeloos, P. (1980). New aspects of the use of inert diets for high density culturing of brine shrimp. In: Persoone, G., Sorgeloos, P., Roels, O. A., Jaspers, E. (eds) The brine shrimp Artemia, Vol. 3, Ecology, culturing, use in aquaculture. Universa Press, Wetteren, Belgium, in press

Fujimura, T (1978). Plan for the development of prawn farming in Thailand and recommendations to increase production of juveniles for distribution to farmers and for stocking natural areas. FAO Report THA/75/008/78/WP 2,18 pp

Gilchrist, B. M. (1960). Growth and form of the brine shrimp, Artemia salina (L.). Proc. zool. Soc. Lond. 134 (2): 221-235

Girin, M. (1979). Some solutions to the problem of producing juvenile marine finfishes for aquaculture. In: StyczynskaJurewicz, E., Backiel, T., Jaspers, E., Persoone, G. (eds) Cultivation of fish fry and its live food. European Mariculture Society, Spec. Publ. no. 4, Bredene, Belgium, pp. 199-209
Kinne, O. (1977). Cultivation of animals: research cultivation. In: Kinne, O. (ed.) Marine ecology, Vol. III, Cultivation. Wiley, London, pp. 579-1293

Persoone, G., Sorgeloos, P., Roels, O. A., Jaspers, E. (1980). Editorial note on Artemia taxonomy. The brine shrimp Artemia, Vol. 1, 2 and 3. Universa Press, Wetteren, Belgium, in press

Purdorn, C. E., Preston, A. (1977). A fishy business. Nature, Lond. 266: 396-397

Sick, L. V., Beaty, H. (1974). Culture techniques and nutrition studies for larval stages of the grant prawn, Macrobrachium rosenbergii. Georgia Marine Science Center, University System of Georgia, Skidaway Island, Georgia, Technical Report Series, no. 74-5, $30 \mathrm{pp}$

Sokal, R. R., Rohlf, F. J. (1969). Biometry, W. H. Freeman and Co., San Francisco

Sorgeloos, P. (1975). De invloed van abiotische en biotische faktoren op de levenscyclus van het pekelkreeftje, Artemia salina L. Thesis, State University of Ghent

Sorgeloos, P. (1980). The use of Artemia in aquaculture. In: Persoone, G., Sorgeloos, P., Roels, O. A., Jaspers, E. (eds) The brine shrimp Artemia, Vol. 3, Ecology, culturing, use in aquaculture. Universa Press, Wetteren, Belgium, in press

Sorgeloos, P., Baeza-Mesa, M., Benijts, F., Persoone, G. (1976). Current research on the culturing of the brine shrimp Artemia salina L. at the State University of Ghent, Belgium. In: Persoone, G., Jaspers, E. (eds) Proceedings 10th European symposium on marine biology, Vol. 1. Universa Press, Wetteren, Belgium, pp. 473-495

Sorgeloos, P., Baeza-Meza, M., Bossuyt, E., Bruggeman, E, Dobbeleir, J., Versichele, D., Laviña, E., Bernardino, A. (1980). The culture of Artemia on ricebran: the conversion of a waste-product into highly nutritive animal protein. Aquaculture, in press

Sorgeloos, P., Bossuyt, E, Bruggeman, E., Cooreman, A., Dobbeleir, J. Vanhaecke, P., Versichele, D. (1979). Progress report on the research activities of the Artemia Reference Center Coun. Meet. int. Coun. Explor. Sea, ICES C. M./F. 54: 206-214

Stephens, D. W., Gillespie, D. M. (1972). Community structure and ecosystem analysis of the Great Salt Lake. In: Riley, T. P. (ed.) Proceedings Annual Conference of the Utah Section of the American Water Resources Association. Great Salt Lake and Utah's water resources, Salt Lake City, Utah (No. 30, 1972) Utah Water Res. Lab., Utah State University, pp. $66-72$

Tobias, W. J., Sorgeloos, P., Roels, O. A., Sharfstein, B. A. (1980). International Study on Artemia. XIII. A comparison of production data of 17 geographical strains of Artemia in the St. Croix Artificial Upwelling Mariculture System. In: Persoone, G., Sorgeloos, P., Roels, O. A., Jaspers, E. (eds) The brine shrump Artemia, Vol. 3, Ecology, culturing, use in aquaculture. Universa Press, Wetteren, Belgium, in press

Vanhaecke, P., Cooreman, A. (1979). Vergelijkende studie van de geografische rassen van het pekelkreeftje, Artemia salina (L.). Jaarverslag F. K. F. O. 2.0010.78

Vanhaecke, P., Sorgeloos, P. (1980). International Study on Artemia. IV. The biometrics of Artemia strains from different geographical origin. In: Persoone, G., Sorgeloos, P., Roels, O. A., Jaspers, E. (eds) The brine shrimp Artemia, Vol. 3, Ecology, culturing, use in aquaculture. Universa Press, Wetteren, Belgium, in press

Versichele, D., Sorgeloos, P. (1980). Controlled production of Artemia cysts at laboratory scale. In: Persoone, G., Sorgeloos, P., Roels, O. A., Jaspers, E. (eds) The brine 
shrimp Artemia, Vol. 3, Ecology, culturing, use in aquaculture. Universa Press, Wetteren (Belgium), in press Walne, P. R. (1967). The food value of 13 different species of unicellular algae to Artemia salina. Coun. Meet. int. Coun. Explor. Sea, ICES C.M./E 5: 1-7

This paper was presented by Professor G. Persoone; it was accepted for printing on August 8, 1980 